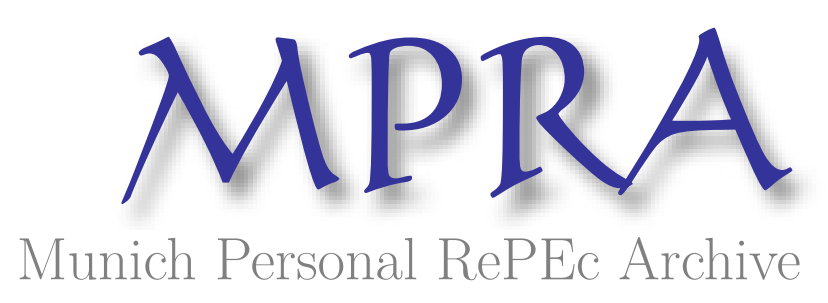

\title{
The developmental role of SMEs in the Arab countries
}

\author{
Elasrag, Hussein
}

August 2012

Online at https://mpra.ub.uni-muenchen.de/40608/

MPRA Paper No. 40608, posted 11 Aug 2012 13:25 UTC 


\title{
The developmental role of SMEs in the Arab countries
}

\author{
HUSSEIN ELASRAG \\ Egyptian Ministry of Industry and Foreign Trade \\ E.Mail: elasrag@gmail.com
}

\begin{abstract}
Small and medium enterprises (SMEs) have become one of the key instruments to face economic and social problems and achieve development objectives in most industrial and developing countries. SME contributions to employment creation, productivity improvement, and income generation are underutilized in the Arab countries at a time when economic transformation is shifting the onus for productivity from the public sector to the private sector. Population growth and economic restructuring in many Arab countries make the creation of substantial new employment opportunities a necessity. To do so, Arab enterprises must favorably face increased competition in both local and export market through improvements in product quality and work place efficiency. Sheer survival in theses business conditions forces both large companies and SMEs to restructure themselves in order to meet the global competition. Statistics show that SMEs represent $90 \%$ of total companies in the vast majority of economies worldwide and provide $40-80 \%$ of total job opportunities in addition to contributing largely to GDPs of many countries. The aim of this research is to study The developmental role of SMEs in the Arab countries.
\end{abstract}




\section{Contents}

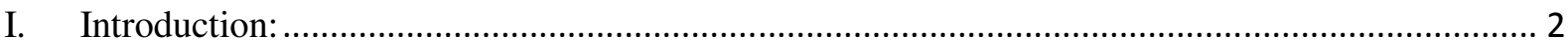

II. Small and medium enterprises in the Arab countries (definition and importance)........................ 2

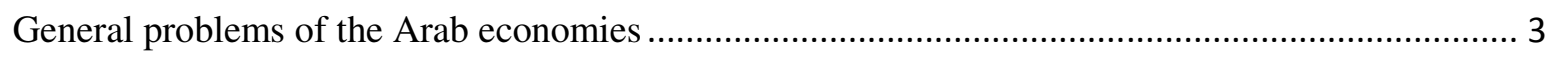

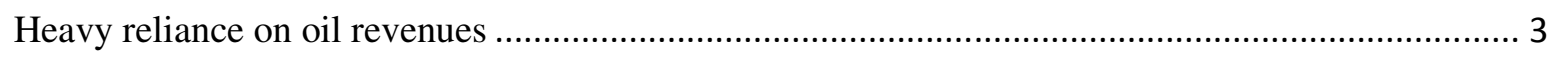

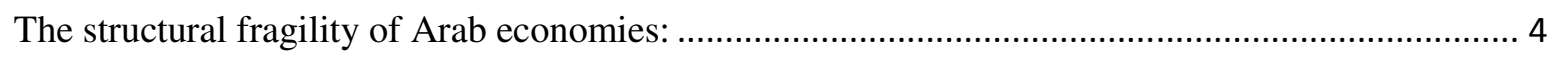

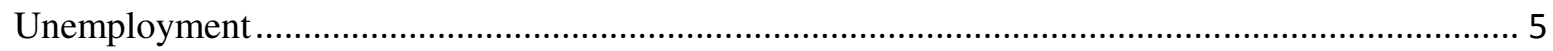

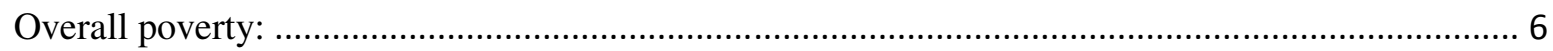

Definitional Aspects of small and medium enterprises:.............................................................. 7

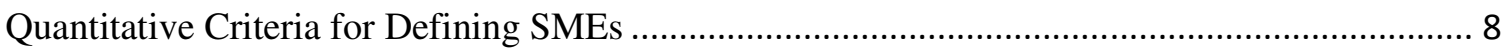

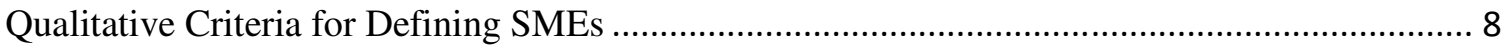

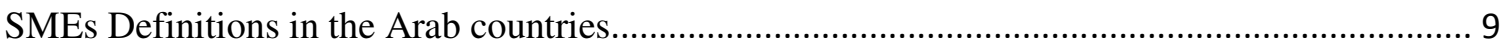

III. The importance of SMEs for the Arab countries ..................................................................... 9

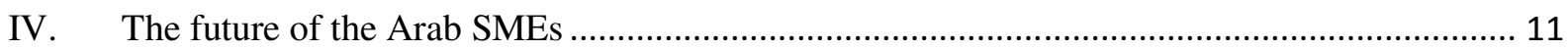

Promoting a realistic understanding of the economic potential of M/SMEs..................................... 11

Avoiding politicization of the issues and programs of M/SME development. .................................... 12

Maintaining a tight integration between SME policies and programs and the overall economic orientation towards increased competitiveness. .......................................................................... 12

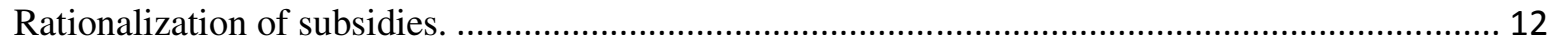

Using best practices and results of scientific research in design and implementation..................... 12

Promoting a Regulatory Environment Conducive to the Development of SMEs............................ 12

Creating a favorable business environment for SME .................................................... 13

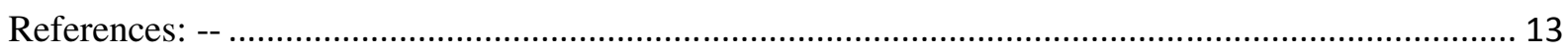




\section{Introduction:}

Statistics show that SMEs represent $90 \%$ of total companies in the vast majority of economies worldwide and provide $40-80 \%$ of total job opportunities in addition to contributing largely to GDPs of many countries. For example, SMEs constitute more than $99 \% 1$ of all nonagricultural private enterprises in Egypt and account for nearly three-quarters of new employment generation. for Kuwait, this sector constitutes approximately $90 \%$ of the private workforce, including labor and imported an estimated $45 \%$ of the labor force, employment and national rates of less than $1 \%$, in Lebanon, more than $95 \%$ of the total enterprises, contribute about $90 \%$ of the jobs. In the UAE, small and medium enterprises accounted about $94.3 \%$ of the economic projects in the country, and employs about $62 \%$ of the workforce and contributes around $75 \%$ of the GDP of the state. In addition, they account for $96 \%$ of the GDP in Yemen in 2005, and about 77\%, 59\%, 25\% in Algeria, Palestine and Saudi Arabia, respectively, during the same year.It is often argued that the Governments should promote SMEs because of their greater economic benefits compared to the large firms in terms of job creation, efficiency and growth.Following are the major driving force to strengthen SMEs in the Arab countries:

(1) SMEs are the important vehicle in terms of employments and poverty alleviation. SME employs a large share of the labour force in many Arab countries.

(2) SMEs make significant contributions to the national economy of the country; and Can be a tool to accelerate the growth of exports.

(3) SMEs foster an entrepreneurial culture and make the economy more resilient to the global fluctuations.

The aim of this research is to study The developmental role of SMEs in the Arab countries.

\section{Small and medium enterprises in the Arab countries (definition and importance)}

Promoting (SMEs) have been one of the best strategies for achieving economic development. Many Arab countries have recognized the importance of small and medium-sized enterprises (SMEs), and have formulated policies to encourage, support, and fund there. The benefits of SMEs to any economy are easily noticeable, they include: contribution to an economy in terms of creation of jobs, development of skilled and semi-skilled workers, and developing and adapting appropriate technological approaches. This section discusses the developmental role of small and medium-sized enterprises (SMEs) in the Arab countries.

Well-managed and healthy SMEs are a source of employment opportunities and wealth creation. They can contribute to social stability and generate tax revenues. According to the International Finance Corporation (IFC), there is a positive relationship between a country's overall level of income and the number of SMEs per 1,000 people. The World Bank's Doing Business reports indicate that a healthy SME sector corresponds with a reduced level of informal or "black market" activities. ${ }^{1}$ Support for SMEs usually aims to assist in the creation of employment opportunities in general and for the employment of marginal populations in particular.Statistics show that SMEs represent $90 \%$ of total companies in the vast majority of

\footnotetext{
${ }^{1}$ World Business Council for Sustainable Development ( WBCSD),.Promoting SMEs for Sustainable Development.. WBCSD, July 2007,p2
} 
economies worldwide and provide $40-80 \%$ of total job opportunities in addition to contributing largely to GDPs of many countries. For example, SMEs constitute more than 99\%1 of all non-agricultural private enterprises in Egypt and account for nearly three-quarters of new employment generation. for Kuwait, this sector constitutes approximately $90 \%$ of the private workforce, including labor and imported an estimated $45 \%$ of the labor force, employment and national rates of less than $1 \%$, in Lebanon, more than $95 \%$ of the total enterprises, contribute about $90 \%$ of the jobs. In the UAE , small and medium enterprises accounted about $94.3 \%$ of the economic projects in the country, and employs about $62 \%$ of the workforce and contributes around $75 \%$ of the GDP of the state. In addition, they account for $96 \%$ of the GDP in Yemen in 2005, and about 77\%, 59\%, 25\% in Algeria, Palestine and Saudi Arabia, respectively, during the same year.

It is often argued that the Governments should promote SMEs because of their greater economic benefits compared to the large firms in terms of job creation, efficiency and growth.

Following are the major driving force to strengthen SMEs in the Arab countries:

(1) SMEs are the important vehicle in terms of employments and poverty alleviation. SME employs a large share of the labour force in many Arab countries.

(2) SMEs make significant contributions to the national economy of the country; and $\mathrm{Can}$ be a tool to accelerate the growth of exports.

(3) SMEs foster an entrepreneurial culture and make the economy more resilient to the global fluctuations.

Despite remarkable progress in a many Arab countries, the majority of the developing countries have found that the impact of their SME development programs on enterprise performance has been less than satisfactory. However, it has been acknowledged that Micro enterprise and SMEs are the emerging private sector and these form the base for privatesector led growth.So, In order to reflect the important role that can be played by SMEs in the development of Arab States I think it's important to identify the problems facing these countries. Then illustrate the importance of these projects for the Arab States. And then indicate what can be done to address these problems through the development of the SMEs.

\section{General problems of the Arab economies}

The economies of the Arab countries lack diversity, a situation which has remained unchanged since the early 1990s. Oil exports are still the main economic engine of the region. Many people,

not only in the oil-rich countries, have private incomes and there is still secondary dependence on oil revenue throughout the region.

Regional cooperation is a slogan with no economic pressure from the private sector or genuine political will behind it. External indebtedness is massive and continues to sap the region's energies. Domestic savings are insufficient to finance investment, and consumption levels are still high in most Arab economies. Particular problems include:

\section{Heavy reliance on oil revenues}

Arab GDP growth since the 1970s has been closely tied to the rise in export revenues, dominated by fuel exports. The latter constituted 75, 72.6 and 81.4 per cent of merchandise exports of the high income (Bahrain, Kuwait, Qatar, Saudi Arabia, and the United Arab Emirates), middle income (Lebanon, Libya, and Oman, Algeria, Djibouti, Egypt, Jordan, Morocco, Syria, Tunisia) and low income (Comoros, Mauritania, Sudan, and Yemen) groups respectively in 2006. The fitful ups-and-downs in the Arab countries, from high growth in the 
1970s to economic stagnation through the 1980s and back to extraordinary growth in the early 2000s directly reflects the turbulent cycles of the oil market. This is illustrated both by Figure 1, which shows the strong link between movements of the global oil price and the region's GDP growth.

\section{Figure 1: Regional GDP growth based on constant 1990 prices, and growth in nominal oil prices,1976-2007}

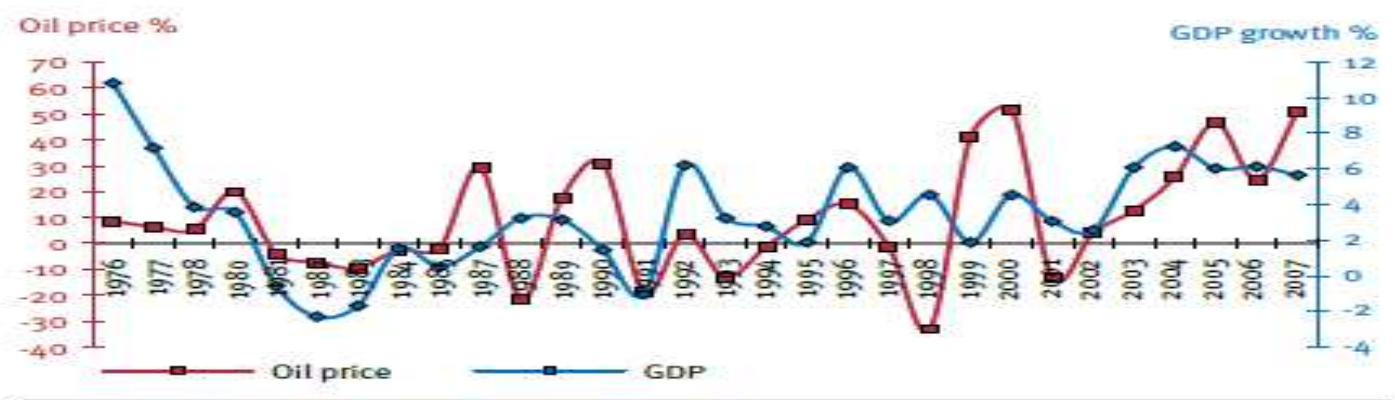

Source: UNDP/AHDR calculations based on UNSD 2008.

Notes: Data for 1979 and 1986 were removed from the graph as they were significant outliers.

The steep drops in oil income during the 1980s had major impacts on oil producing countries (Saudi Arabia, for example, saw its GDP at current prices halved between 1981 and 1987). A number of other countries experienced negative economic growth, of which the hardest hit was Kuwait, where GDP at current prices declined by around 18 per cent in 1981 and 1982. The shocks were transmitted to non oil Arab economies whose receipts from remittances fell away. Jordan and Yemen both had negative growth in some years. Through all the ups and downs during nearly two and half decades after 1980, the region's per capita economic growth hardly increased at all. Based on World Bank data, real GDP per capita in the Arab countries rose by a mere 6.4 per cent over the entire 24 year period from 1980 to 2004 (i.e. by less than 0.5 per cent annually). Since the 1990s, real per capita growth rates in non oil as well as oil countries have fluctuated erratically, often turning negative. ${ }^{2}$

\section{The structural fragility of Arab economies:}

Oil-led growth has created weak structural foundations in Arab economies. Many Arab countries are turning into increasingly import oriented and service based economies. The types of services found in Arab countries fall at the low end of the value adding chain, contribute little to local knowledge development, and lock countries into inferior positions in global markets. This trend, which has been at the expense of Arab agriculture, manufacturing and industrial production, is therefore of concern. Although the share of services in regional GDP declined quite significantly from over 60 per cent in 1986 to 45 per cent in 2007, this was largely due to the rise in share of the oil sector. By the year 2007, the share of services in GDP still exceeded 50 per cent in all non-oil producing Arab countries and was above 65 percent in Bahrain, Djibouti, Jordan, Lebanon and Morocco. Furthermore, the sector accounted for over 50 per cent of total employment in most Arab countries.

${ }^{2}$ The United Nations Development Programme, Arab Human Development Report 2009:

Challenges to Human Security in the Arab Countries, New York, USA,2009,PP100-101 
Not surprisingly, most Arab countries have experienced significant deindustrialization over the last four decades (Figure 2). In fact, the Arab countries were less industrialized in 2007 than in 1970 , almost four decades ago. ${ }^{3}$

Figure 2: Change in the share of manufacturing to GDP (\%), 1970 to 2007,

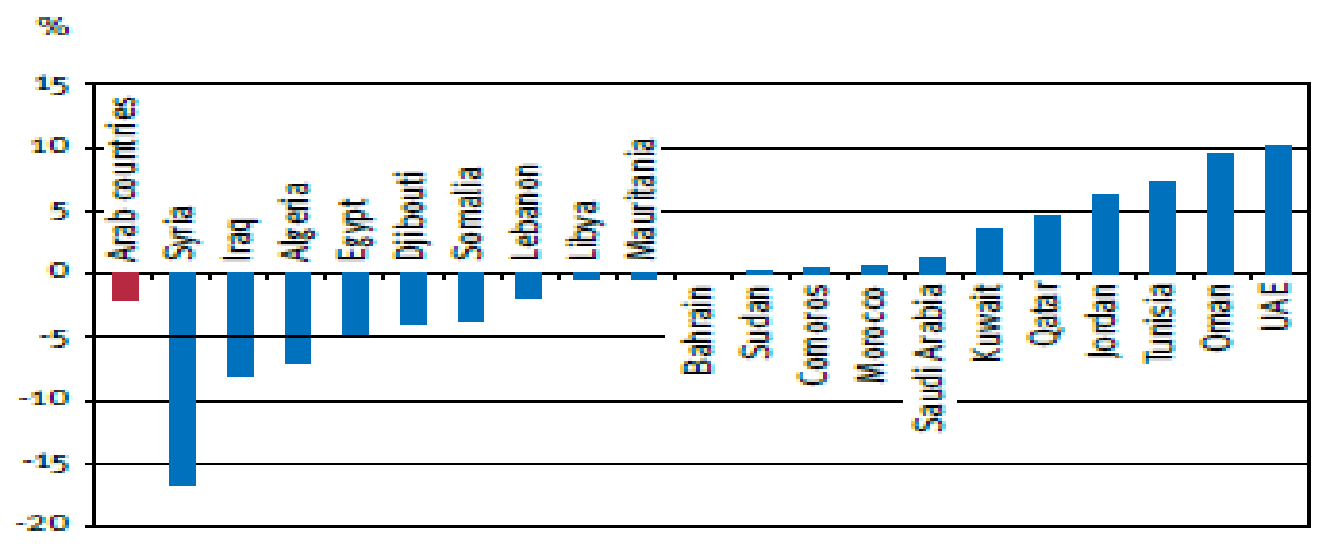

Source: The United Nations Development Programme, Arab Human Development Report 2009: Challenges to Human Security in the Arab Countries, New York, USA,2009,p105

This includes middle income with a relatively diversified economic base in the 1960s, such as Algeria, Egypt, Iraq and Syria. True, Jordan, Oman, Tunisia, and UAE have made noticeable progress in industrial development. Nonetheless, in general, the contribution of manufacturing to GDP is anemic, even in Arab countries that have witnessed rapid industrial growth and especially when compared to the shares of other developing countries such as the East Asian economies. For the majority of Arab countries, manufactured goods made up less than 11 per cent of total commodity exports in for the year 2006/2007.8 Moreover, all country groups appear to be converging on the modest regional average, which was below 10 per cent in 2007, from an initially diverse sub regional industrial base in 1970. Finally, the structural fragility of Arab economies as a result of oil-led growth is highlighted by the conspicuous decline in the share of non-oil productive sectors (agriculture and manufacturing) to GDP in all Arab countries except the high income countries. It should be noted that the rapid increase in manufacturing shares in the latter is due, in part, to the very low initial base in the 1970s and the rapid growth in value added by petrochemical industries.

\section{Unemployment}

Data from the Arab Labour Organization show that in 2005 the overall average unemployment rate for the Arab countries was about 14.4 per cent of the labour force compared to 6.3 per cent for the world at large. While national unemployment rates vary considerably, ranging from about 2 per cent in Qatar and Kuwait to about 22 per cent in Mauritania, as noted subsequently, youth unemployment is a serious challenge common to many Arab countries.

Figure3- A: Unemployment rate among Arab youth in the year 2005/2006

3 Ibid,p 103 


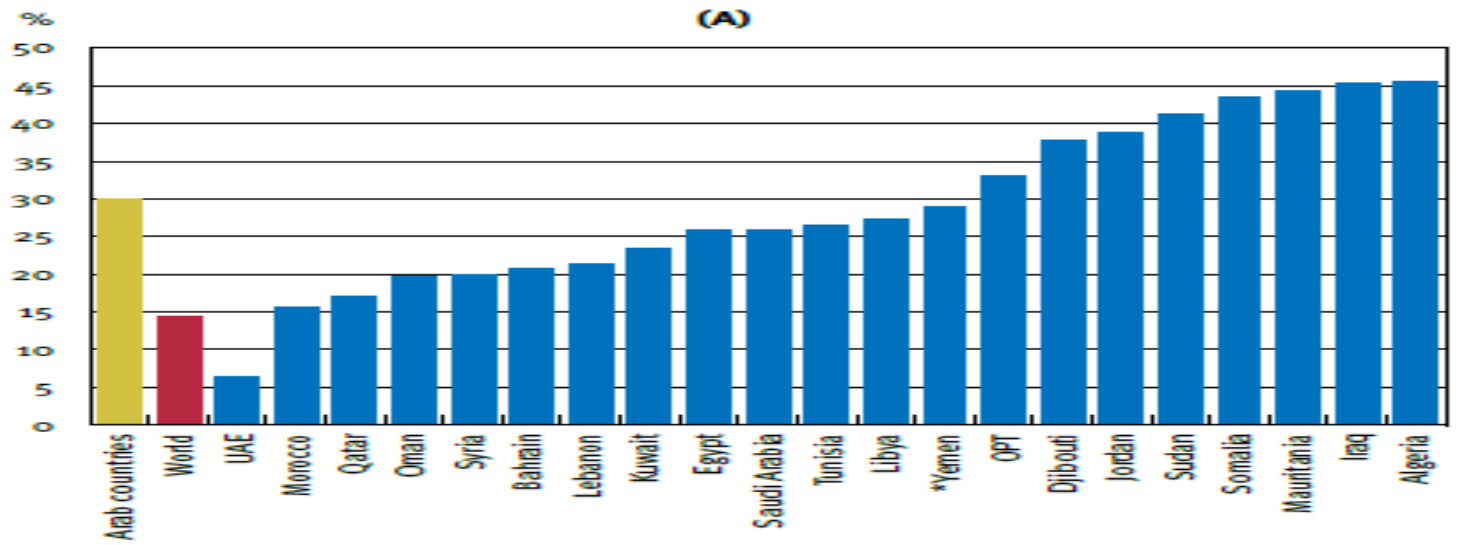

Source: The United Nations Development Programme, Arab Human Development Report 2009,Ibid,p 109

ALO estimates for the year 2005/2006 show that youth unemployment rates vary from a high of about 46 per cent in Algeria to a low of 6.3 per cent in the UAE. Unemployment in the Arab countries not only affects youth disproportionately; it also often wears a female face. Unemployment rates for young Arab women are higher than those for young Arab men, and among the highest in the world. ALO data for the year 2005 shows that the youth unemployment rate for men was 25 per cent of the male labour force compared to 31.2 per cent for women.

\section{Figure3- B: Share of Arab youth in total unemployment (\%), in the year 2005/2006}

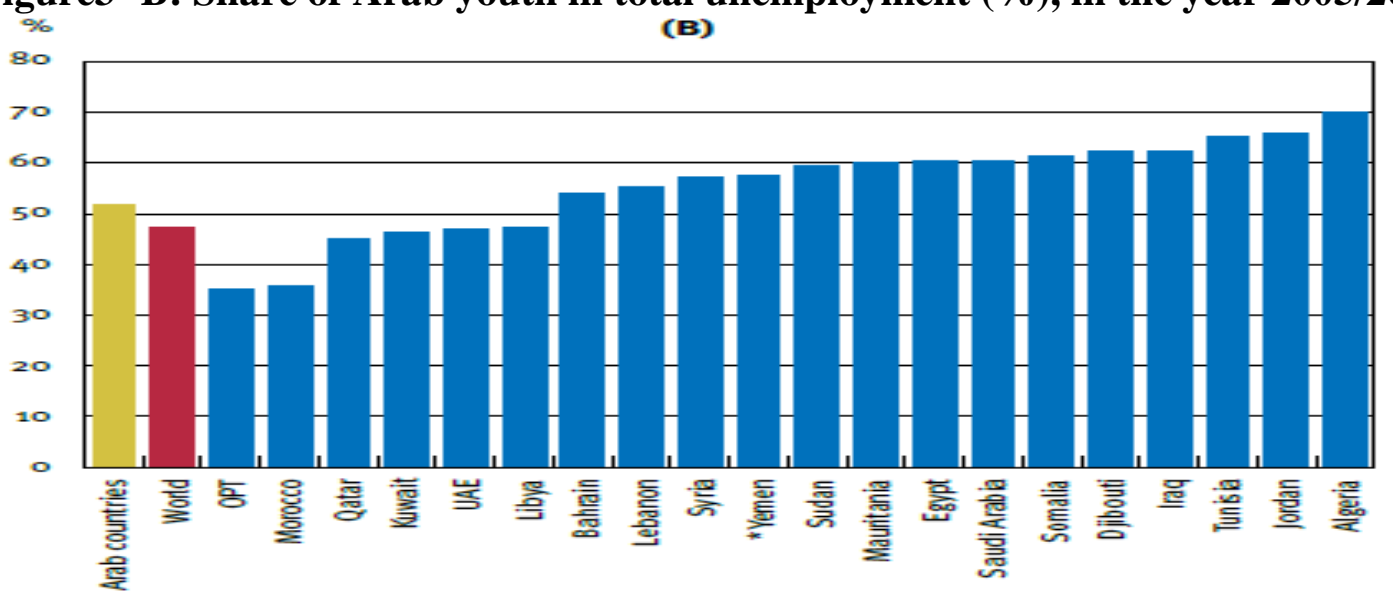

Source: The United Nations Development Programme, Arab Human Development Report 2009,Ibid,p 109

\section{Overall poverty:}

Overall poverty, defined as the share of the population under the national upper poverty line, is significantly higher than the underestimate yielded by using the international poverty line of two dollars a day or lower national poverty lines. The Arab Human Development Report 2009 showed, that overall poverty rate would be in the order of $39.9 \%$. Hence, it concluded that poverty in the Arab countries is a more conspicuous phenomenon than commonly assumed despite these countries' relatively high average per capita expenditure. The 
explanation is simple: the great majority of the poor are concentrated in countries such as Egypt, Iraq, Mauritania, Morocco, Somalia, Sudan, Syria and Yemen with relatively large populations and lower than average per capita expenditure shares. Regardless of the choice of poverty line (national or international), the region has made no significant progress on the poverty reduction front in the 2000 s if the 1990 s are taken as a base period. ${ }^{4}$

\section{Definitional Aspects of small and medium enterprises:}

There is no universally agreed definition of SMEs. Some analyses define them in terms of their total revenue, while others use the number of employees as an indicator. The European Union defines a medium-sized enterprise as one with a headcount of 250 , a small firm as one with a headcount of less than 50 and a micro enterprise as one with a maximum of 10 employees. To qualify as an SME in the European Union, a firm must have an annual turnover of Euro 40 million or less and/or a balance sheet valuation not exceeding Euro 27 million, while the annual turnover of a micro enterprise must not exceed Euro 2 million.

The OECD adopts the following convention for categorizing SMEs --micro: 1-4 employees; very small: 5-19 employees; small: 20-99 employees; medium: 100-500 employees. ${ }^{5}$

In most of the OECD countries, for example, work force size is regarded as the main criterion. However, what is termed a small manufacturing enterprise may have up to 50 employees in Belgium and Greece, up to 100 in the United States, up to 200 in Canada, Italy and Spain, and up to 500 in Denmark, France, Germany and Ireland. In nearly all these countries, enterprises with fewer than 10 or fewer than 20 employees are regarded either as very small enterprises or micro-enterprises, or are excluded from official statistics.

In addition, there is no single definition of SMEs among officials of the multilateral development institutions, each thinking within the context of the official definition of his or her own institution, as represented below by the maximum size criteria for SMEs.

Table 1: SME Definitions Used by Multilateral Institutions

\begin{tabular}{|l|c|c|c|}
\hline Institution & $\begin{array}{l}\text { Maximum \# of } \\
\text { Employees }\end{array}$ & $\begin{array}{l}\text { Max. Revenues or } \\
\text { Turnover (\$) }\end{array}$ & $\begin{array}{l}\text { Maximum } \\
\text { Assets (\$) }\end{array}$ \\
\hline World Bank & 300 & $15,000,000$ & $15,000,000$ \\
\hline MIF - IADB & 100 & $3,000,000$ & (none) \\
\hline African Development Bank & 50 & (none) & (none) \\
\hline Asian Development Bank & \multicolumn{2}{|c|}{$\begin{array}{c}\text { No official definition. Uses only definitions of } \\
\text { individual national governments. }\end{array}$} \\
UNDP & 200 & (none) & (none) \\
\hline
\end{tabular}

Source:Tom Gibson,H. J. van der Vaart,Defining SMEs:A Less Imperfect Way of Defining Small and Medium Enterprises in Developing Countries, September 2008,p5.

\footnotetext{
4 Ibid,p116

${ }^{5}$ Meghana Ayyagari, Thorsten Beck, and Asli Demirgüç-Kunt , Small and Medium Enterprises across the Globe:A New Database,World Bank Policy Research Working Paper 3127, August 2003.p8
} 
It is apparent in the analysis that three main quantitative parameters are commonly used in the SMEs definitions. In addition to these quantitative parameters, a few countries have added qualitative criteria into their definitions of the M/SME sector. It is important to cover both the quantitative aspects and the qualitative measures. ${ }^{6}$

\section{Quantitative Criteria for Defining SMEs}

Quantitative analysis of SMEs primarily consists of the following criteria:

1) Number of employees: This is the most widely used criterion to define SMEs. Normally, micro-enterprises are defined as those entities that employ between one to nine workers; small enterprises employ from five, ten or 15 up to 49 workers; and medium enterprises usually employ from 50 up to 250 workers in some countries. It obvious that the literature contains different definitions for micro, small and medium enterprises, and this difference depends primarily on the degree of development of the countries in question.

2) Value of fixed assets: This criterion is also used by a number of countries. However, it is not used as commonly due to the difficulty for some enterprises to determine a precise value of their fixed assets and hesitance of some enterprise owners to reveal this type of information to the outside world. Classifying enterprises by this criterion differs not only from one country to another (according to its stage of development), but also from one sector to another. In all cases where the value of fixed assets is used, it is linked to the number of employees criterion.

3) Turnover per enterprise: This criterion may also be referred to as the value of sales, gross receipts or output per establishment. This criterion for defining SMEs is correlated to other quantitative criteria, such as the number of employees or the value of fixed assets.

\section{Qualitative Criteria for Defining SMEs}

Of the international and local country definitions, only Australia and the United States include qualitative criteria in their official definitions of a small business. The qualitative measures tend to focus on particular characteristics of SMEs that are inherent in their nature. some of the SMEs qualitative criteria, including: (a)management and ownership are rarely separate; (b) control over business operations and decisions reside with one or two persons who are usually family members; (c) project's equity is not publicly traded; (d) personal security of the owners is required to secure debt acquisition and repayment; (e) the level and number of formal contractual relations are kept at a minimum level; and (f) personal objectives of the owners guide and influence business decisions directly.

Examples of qualitative definitions in the US include those of the US Congress and the Committee for Economic Development. The US Congress defines a small business as being one that is owned independently and does not carry a dominant market position. The

\footnotetext{
${ }^{6}$ Doha Abdelhamid and Alia El Mahdi,The Small Business Informality Challenge: Lessons Learned From Country Experiences and The Road Ahead of Egypt, ERF Working Paper Series, Economic Research Forum, Working Paper 0324 ,pp3-5
} 
Committee for Economic Development defines a small business as having at least two of the following features: (a) independence in management since the manager usually owns the business; (b) the supply of capital and ownership is controlled by an individual or a few individuals; (c) the area of operation is primarily local, although the market is not necessarily domestic; and (d) the presence of a business is seen as being small when compared to larger competitors in the industry.

Qualitative measures cannot be used aloof of quantitative measures. The Australian committee was primarily initiated to provide guidance to small business management and enable them to be more efficient with a specific focus on small manufacturing. The committee suggested that a small business should be defined as: 'A business in which one or two persons are required to make all the critical management decisions: finance, accounting, personnel, purchasing, processing or servicing,marketing, selling, without the aid of an internal specialist and with specific knowledge in only one or two functional areas.' The definition incorporated a quantitative guideline that small businesses would normally employ 100 employees .Other researchers have also support linking quantitative measures to qualitative ones.

\section{SMEs Definitions in the Arab countries}

The term SMEs covers a wide range of definitions and measures, varying from country to country and between the sources reporting SMEs statistics. Some of the commonly used criteria are the number of employees, total net assets, sales and investment level. However, the most common definitional basis used is employment, and here again, there is variation in defining the upper and lower size limit of an SMEs. Despite this variance, a large number of sources define an SMEs to have a cut-off range of 0-250 employees. Similarly, in the Arab countries and elsewhere in the world, the definitions of a micro-, small, medium and large enterprise vary widely. In Yemen, for example, a small enterprise is one employing fewer than four workers, a medium-sized enterprise is one that employs between two and nine workers, and a large enterprise is one that has more than 10 employees. In Jordan, a small enterprise is one with between four and 10 employees and a medium-sized enterprise is one with between 10 and 25. Micro-businesses are those with up to four employees. In Egypt a SME is a paid capital of no more than LE1 million and no more than 50 workers.

\section{The importance of SMEs for the Arab countries}

There is a rich body of research on the development contribution of SMEs. While not entirely without some controversial areas, there would appear to be widespread consensus on the following points. ${ }^{7}$

- SMEs (partly because of the industrial sub-sectors and product groups covered by them) tend to employ more labour-intensive production processes

than large enterprises. Accordingly, they contribute significantly to the provision of productive employment opportunities, the generation of income and ultimately, the reduction of poverty. It is essentially through the promotion of SMEs that individual countries and the

\footnotetext{
${ }^{7}$ Luetkenhorst, W. (2004) 'Corporate Social Responsibility and the Development Agenda: The case for actively involving small and medium enterprises', Intereconomics, May/June.p159
} 
international community at large can make progress towards reaching the Millennium Development Goal of halving poverty levels by the year 2015 .

- There is ample empirical evidence that countries with a high share of small industrial enterprises have succeeded in making the income distribution (both

regionally and functionally) more equitable. This in turn is a key contribution to ensuring long-term social stability by alleviating ex-post redistributional pressure and by reducing economic disparities between urban and rural areas.

- SMEs are key to the transition from agriculture-led to industrial economies as they provide simple opportunities for value-adding processing activities which can generate sustainable livelihoods. In this context, the predominant role of women is of particular importance.

- SMEs are a seedbed for entrepreneurship development, innovation and risk-taking behavior and provide the foundation for long-term growth dynamics and the transition towards larger enterprises.

- SMEs support the building up of systemic productive capacities. They help to absorb productive resources at all levels of the economy and contribute to the creation of resilient economic systems in which small and large firms are interlinked.

- Such linkages are of increasing importance also for the attraction of foreign investment. Investing TNCs seek reliable domestic suppliers for their supply chains. There is thus a premium on the existence of domestic supporting industries in the competition for foreign investors.

- SMEs, as amply demonstrated in information and communication technologies, are a significant source of innovation, often producing goods in niche markets in a highly flexible and customised manner.

As the above non-exhaustive list demonstrates, the development contributions of SMEs are varied and can be found at the intersection of economic and social dimensions: SMEs foster economic cohesion by linking up with, and supporting, larger enterprises, by serving niche markets and in general by contributing to the build-up of systemic productive capacities. At the same time, SMEs foster social cohesion by reducing development gaps and disparities, thus spreading the gains of economic growth to broader population segments and backward regions.

In fact, an urgent need for the development of small and medium enterprises in the Arab States for the following reasons:

1 - These projects constitute about $99 \%$ of the total private business, non-agricultural in Egypt, and contribute about $80 \%$ of the total added value produced by the private sector, with about two-thirds of the labor force and three-quarters of workers in special functions outside the agricultural sector. for Kuwait, this sector constitutes approximately $90 \%$ of the private workforce, including labor and imported an estimated $45 \%$ of the labor force, employment and national rates of less than $1 \%$, in Lebanon, more than $95 \%$ of the total enterprises, contribute about $90 \%$ of the jobs. In the UAE, small and medium enterprises accounted about 
$94.3 \%$ of the economic projects in the country, and employs about $62 \%$ of the workforce and contributes around $75 \%$ of the GDP of the state.

2 - SMEs are one of the effective solutions for eliminating unemployment SMEs providing job opportunities to a broad base of Arab labor force estimated at about one third of the labor force or more.

3 - SMEs involved in the addendum to the national economy with an estimated contribution of $96 \%$ of the GDP in Yemen in 2005, and about 77\%, 59\%, 25\% in Algeria, Palestine and Saudi Arabia, respectively, during the same year, while the contribution of these projects range between $25 \%-40 \%$ of the GDP of Egypt.

4-Employing semi-skilled workforce: Using mostly simple equipment and materials, SMEs attract semi-skilled workers who are available in the Arab countries.

5 - SMEs support and strengthen the role of the private sector in economic activity.

6-Assisting in social and political stability: Socially speaking, SMEs provide job opportunities for those classes who lack financial or academic capabilities to positively participate in the production process. This results in eliminating the tension wrapping the relationship between social classes.

7- SMEs help attract more foreign investment to the Arab economies.

8-Create livelihoods for millions of poor families and households

\section{The future of the Arab SMEs}

Related to competitiveness in the global knowledge economy through the upgrading of the new research and development and innovation, and technological development, and continuous improvement in products, and the presence of human resource base has a wire, multi-skilled and has the potential technical and technological resources, among other factors. And to build a competitive sector of small and medium enterprises, there must be compliance with several key pillars:

\section{Promoting a realistic understanding of the economic potential of M/SMEs.}

It is necessary for all stakeholders to share a realistic understanding of M/SMEs and their potential. Misguided political pressures can have devastating results on M/SME policy making and implementation. The separation of myth from reality with regards to various pertinent issues including the role of SMEs in employment generation, as well as their role with regards to youth and new graduates, etc. is a prerequisite for sound policy formulation and policy making. Well-planned and executed public awareness campaigns can play a positive role in this regards. 


\section{Avoiding politicization of the issues and programs of M/SME development.}

It is important to minimize political interference and pressures on the development and implementation of these programs. Programs should be focused on the attainment of developmental results, rather than immediate political returns. Political interference usually compromises professionalism and efficiency, and increases the likelihood that resources will be misallocated and misused.

\section{Maintaining a tight integration between SME policies and programs and the overall economic orientation towards increased competitiveness.}

With the lack of such integration, there is a risk of ending up with a disjointed policy framework that does little, if any to serve the sector, let alone serve the economy as a whole. Across the board, economic development strategies should be revised to provide for the integration of SMEs and the various services and policies needed for their development.

\section{Rationalization of subsidies.}

While the proposed measures entail sizeable investments and subsidization of many programs and initiatives, it should be kept in mind that subsidies if improperly targeted can have severe distortion effects. Where recommended in this document subsidies were aimed at rectifying market failures. All subsidized interventions should be carefully considered in order to maximize their benefits and minimize their setbacks. Unnecessary subsidies should be phased out or discontinued, and reallocated towards the development of market capacities to address specific failures in servicing M/SMEs. Necessary direct subsidies should be tied to the achievement of results.

\section{Using best practices and results of scientific research in design and implementation.}

The government should make better use of the accumulated international and local knowledge, rather than reinvent the wheel, or commit the same mistakes. In addition, this will assist in developing realistic targets and expectations.

\section{Promoting a Regulatory Environment Conducive to the Development of SMES}

Building a regulatory environment that facilitates SME development should be a major consideration when developing economic and regulatory reform efforts. In each,alleviating the regulatory burden on operating SMEs and eliminating impediments to the market access expansion of SMEs are critical goals. Many countries have sought to lessen the regulatory burden on SMEs though by implementing programs aimed at reducing paperwork, minimizing administrative burdens, and reducing compliance costs.

\section{A- Creating a level playing field:}

A key component of a successful SME development strategy is the establishment of a business environment that helps SMEs compete on a more equal basis. To establish a level playing field for SMEs, governments need to:

_ Re-evaluate the costs and benefits of regulations that place a disproportionate burden on SMEs

_ Implement regulations with the flexibility needed by SMEs

_ Place greater emphasis on competition and opening procurement practices to small firms.

This requires instituting policy and institutional reforms that improve the business environment facing SMEs. For example, it can change regulatory and legal frameworks 
governing competition, investment, commercial transactions, labor regulations, taxes, property rights, and procurement procedures.

\section{B- Legal and regulatory frameworks:}

Laws and regulations help define social structures and many have strong economic impacts. Adequate legal and regulatory frameworks are therefore important prerequisite for economic growth and social development.

\section{Creating a favorable business environment for SME}

With few exceptions, developing countries' experience with BDS so far has been mostly limited to publicly supported programs in the fields of training, marketing and some technology-related areas. Such services, often provided by state agencies and supply driven, have been criticized for being badly planned and managed, their bureaucratic nature, inability to recruit and maintain competent staff, insufficient geographical coverage, lack of coherence and coordination, and an overemphasis on business start-ups and too little focus on the growth trajectory of the enterprise. In addition, their programs fail to address the requirements of globalization, intensification of competition and the knowledge-intensive economy. These include:

Low cost-recovery rates.

Assistance provided was too general and had little benefit to entrepreneurs.

Most of the services were undertaken by government institutions that needed to enhance their efficiency, outreach and quality of services.

$\checkmark$ Lack of qualified staff.

$\checkmark$ Predominance of charity social orientation.

Lack of follow up measures.

Lack of coordination among service providers.

$\checkmark$ Prevalence of supply driven approaches.

Lack of cost-effectiveness.

$\square$ Lack of adequate performance indicators.

\section{References: --}

1. Ayyagari, Meghana, Thorsten Beck, Asli Demirgüc-Kunt, 2005, "Small and Medium Enterprises Across the Globe," World Bank Policy Research Working Paper 3127, World Bank, Washington, D.C.

http://siteresources.worldbank.org/DEC/Resources/84797-1114437274304/SME_globe.pdf

2. Doha Abdelhamid and Alia El Mahdi,The Small Business Informality Challenge: Lessons Learned From Country Experiences and The Road Ahead of Egypt, ERF Working Paper Series, Economic Research Forum, Working Paper 0324

3. Economic and Social Commission for Western Asia,2002," the ability of industrial enterprises of small and medium innovation in selected countries of the ESCWA region", (E/ESCWA/ID/2001/2), the United Nations, New York.

4. Hussien Alasrag, The developmental role of small projects in the Arab countries (Arabic): mpra.ub.uni-muenchen.de/2763/1/MPRA_paper_2763.pdf 
5. Jean-Eric Aubert and Reiffers, Jean-Louis,2003," Knowledge Economies in the Middle East and North Africa: Toward New Development Strategies, WBI Learning Resources Series, The World Bank, Washington, DC .

6. John Houghton and Peter Sheehan, 2000,"A Primer on the Knowledge Economy", Centre for Strategic Economic Studies, Victoria University, Australia,

7. Luetkenhorst, W. (2004) 'Corporate Social Responsibility and the Development Agenda: Thecase for actively involving small and medium enterprises', Intereconomics, May/June.

8. Ministry of Finance, November 2004 ,"Enhancing the competitiveness of small and medium enterprises in Egypt, Arab Republic of Egypt .

9. Ministry of foreign trade, March 2002, streamlining the regulatory procedures for SMEs,Egypt.

10. National bank of Dubai, June 2007,"The Nature of Small and Medium Size Enterprises in GCC's Industrial Sector", Economic report, UAE.

11. Newberry, Derek, 2006. "The Role of Small- and Medium-Sized enterprises in the Futures of Emerging Economies". Earth Trends 2006. World Resources Institute under a Creative Commons License.

12. OECD,18 Apr 2001," Enhancing SME Competitiveness ",The OECD Bologna Ministerial Conference, OECD Publishing.

13. Stevenson, Lois, 2010,"SMEs in the Arab Region: Challenges and Opportunities", The Dubai International Conference of Endowments on Innovative Sources to Finance Small and Medium-Sized Enterprises,UAE,16-17 February

14. Tom Gibson,H. J. van der Vaart, September 2008,"Defining SMEs:A Less Imperfect Way of Defining Small and Medium Enterprises in Developing Countries".

15. UNIDO and the World Summit on Sustainable Development, 2002 ,"CORPORATE SOCIAL RESPONSIBILITY: Implications for Small and Medium Enterprises in Developing Countries", UNITED NATIONS INDUSTRIAL DEVELOPMENT ORGANIZATION Vienna.

16. World Business Council for Sustainable Development ( WBCSD), July 2007,"Promoting SMEs for Sustainable Development", WBCSD. 